\title{
Rethinking Subnational Government Capacity in China
}

\author{
Kyle Jaros ${ }^{1}$ \\ Harvard Kennedy School \\ August 2016
}

\begin{abstract}
It is clear that some subnational governments are better than others at orchestrating major policy programs, yet important questions remain about how and why subnational government capacity varies from case to case. Scholarship that emphasizes political agency in explaining subnational policy outcomes is not always clear as to where such agency comes from. Meanwhile, research that defines the power of subnational units in terms of their formal administrative authority, fiscal capacity, and political status does not fully explain how these structural endowments translate into effective agency. This article works toward a conception of subnational government capacity better able to integrate these approaches and bridge the agency-structure divide. I call for greater attention to the connective structures that enable subnational governments to take the initiative in policymaking and mobilize resources, stressing provinces' internal cohesion and upward political ties. To illustrate the need for a broader conception of subnational capacity, and to show the importance of connective power in action, I analyze the contrasting outcomes of regional development strategies in two Chinese provinces.
\end{abstract}

\section{Keywords}

China; central-local relations; regional development; subnational agency; connective power

\footnotetext{
${ }^{1}$ Kyle Jaros is a China Public Policy Postdoctoral Fellow at the Harvard Kennedy School's Ash Center. His research examines the politics of subnational development and central-local relations in China. He received his Ph.D. from the Department of Government at Harvard University, and starting in September 2016, he will be an Associate Professor in the Political Economy of China at the University of Oxford's School of Interdisciplinary Area Studies. Mailing address: 79 John F. Kennedy Street, Box 74, Cambridge, MA 02138. Email: Kyle jaros@hks.harvard.edu.
} 
The mere fact of administrative decentralization does not ensure that subnational governments are powerful in practice, as scholars like Chung (2000) point out. Provincial authorities in China and other settings vary widely in their ability to orchestrate development and governance strategies - what I refer to here as subnational government capacity. Where economic development is concerned, for example, some Chinese provinces have proven more capable than others of designing and implementing coherent policy programs. Chung (1998) describes Shandong's successful initiatives to promote internationalization in the late 1980s and early 1990s, while Forster (1998) notes the concurrent failure in Zhejiang to craft a coordinated provincial-level economic strategy. Thun (2006) contrasts Shanghai's progress during the 1980s and 1990s in building up an automotive industry cluster with the limited results seen in Beijing. Scholars also point to within-province variation over time in the effectiveness of development policies. Luo and Shen (2009) juxtapose the failures of Jiangsu's regional planning in the Suzhou-Wuxi-Changzhou region in the early 2000s and the greater success of regional policies in the province's Yangtze River corridor over the following years.

Why are some subnational governments better at formulating and implementing major policy initiatives than others? What types of resources or capabilities are necessary for subnational governments to achieve their policy goals? More fundamentally, what does it mean to say a subnational government is powerful? A large body of research has explored the nature and sources of subnational government capacity, yet important questions linger (Yu and Wang 2015). Many China scholars attribute success in regional development and governance initiatives to subnational agency - the adept maneuvering of provincial leaders within a multilevel system (Li 1997; Chung 2000; Donaldson 2011). In China, such work notes, the capacity of subnational governments to achieve their goals is often about taking calculated risks and exploiting opportunities and resources from the central state. However, emphasis on agency begs the question of why proactive leadership and bargaining is found in some cases but not others, and thus calls for more attention to the structural conditions that facilitate subnational agency. Fittingly, a growing body of scholarship, including comparative research on federalism and intergovernmental relations by authors like Marks et al (2008) and Falleti (2010), adopts a structural conception of subnational capacity, examining how different types of authority and resources are distributed between central and subnational governments. Despite its analytical 
rigor, however, such work focuses mainly on the formal powers and resources of subnational units, and does not fully clarify how and when such capacity translates into effective agency.

Building upon these different strands of past research, this article works toward a conception of subnational government capacity that is better suited to large, multilevel polities like China and better able to bridge the agency-structure divide. I define subnational government capacity in dynamic terms as the ability to spearhead initiatives and mobilize resources in a multilevel policymaking system. It is not only the delimited powers and resource endowments of subnational governments that affect their ability to act strategically, I argue, but also their connective power - their internal cohesiveness and the quality of their ties to central leaders and state agencies. Such an approach focuses more attention on the connective structures within provinces and between provinces and the central state that make agency possible.

In the second half of the paper, I use comparative case studies of regional development initiatives in two Chinese provinces during the 2000s to show this conception of subnational government capacity in action. Regional planning has become a key mode of developmental governance in China over recent decades, but outcomes have varied widely, sometimes in counterintuitive ways. In Hunan, a provincial government that was weak by conventional standards proved itself capable of orchestrating a major metropolitan development strategy. I suggest that Hunan's ability to carry off this strategy derived from the provincial establishment's internal cohesion and its leaders' privileged personal ties to the central state. By contrast, Jiangsu province, one of China's economic powerhouses, struggled to carry out a similar metropolitanregional strategy. Jiangsu's difficulty, I argue, can be attributed to the more limited connective power of the provincial establishment, especially its lack of internal political, administrative, and fiscal consolidation. These cases thus highlight the shortcomings of conventional ways of thinking about subnational government capacity, and show the importance of connective power for the success of subnational policy initiatives.

\section{The nature and determinants of subnational government capacity}

The strength of subnational governments is sometimes equated with the degree of independence they enjoy from central authority. But, particularly in hierarchical governance systems like China's, the ability of subnational governments to realize their development and governance goals is as much about working through the larger state apparatus as standing apart 
from it. Far from being autarkic entities, China's provinces are tightly enmeshed in the partystate hierarchy, and governance is a multilevel process. Subnational governments operate in the "shadow of hierarchy" but also in the shade of the central state's umbrella: while they depend on administrative approvals and support from higher levels, they are also able to exploit many opportunities and resources from the state (Heilmann 2009; Zheng 2007; Rithmire 2014).

In a system where the vertical division of powers, responsibilities, and resources across government levels is blurry, it is subnational governments' ability to take action and exert leverage through the larger state, rather than simply their stand-alone power, that counts. What subnational governments can accomplish in their regional development and governance depends partly on their internal capabilities but also partly on the policy benefits and resources they can tap into above. Because resources can be mobilized from various sources, the capacity of subnational governments to get things done depends heavily on political agency - taking action at moments of opportunity, coordinating the efforts of multiple players, and bargaining effectively with actors at other levels.

Indeed, many analyses of policymaking in China and other large, multilevel governance systems have stressed the importance of these types of political agency. As they launch new policies and initiatives, subnational leaders must navigate a gray zone between central demands and local interests. Under China's unitary constitution, central policies set the limits of acceptable subnational behavior, and overtly violating central policies invites political sanction. However, central policies are often vague or internally contradictory, and subnational leaders who act as "pioneers" and carry out policy experiments may be able to exploit ambiguities in central policy in favor of local interests (Chung 2000). ${ }^{2}$ Coordinating the activity and resources of multiple actors behind subnational policy initiatives is also a challenge that requires adept leadership. In a context of bureaucratic fragmentation, orchestrating policy initiatives requires energetic politicians who can break through organizational gridlock and line up support from relevant state institutions (Lieberthal and Oksenberg 1988, 23-24). A further test of subnational agency is to mobilize the political support and material resources from central state actors needed to scale up policy programs and protect them from opposing interests. Insofar as provinces can assert their interests in national political forums, insinuate themselves into "porous" central

\footnotetext{
${ }^{2}$ Chung (2000) gives the example of Anhui's early adoption of rural reforms as an illustration of bold subnational leadership behavior that helped create local economic gains.
} 
decision-making processes, and control central-local "linkages," they can increase the benefits they receive from the center, and curb unwanted interference (Sinha 2005, 15; Gibson 2005). In China, some subnational units have proven better connected or more aggressive in lobbying the center for policy support than others, as scholars like Li (1997) and Lam (2010) note. ${ }^{3}$

If it is clear that effective political agency is crucial for the success of subnational policy programs, however, the challenge with agency-oriented conceptions of subnational capacity is that they beg the question of where such agency comes from. Why are some provinces able to recognize opportunities and boldly take action, while others stay passive? Why are some subnational units better than others at influencing higher-level decisions to their advantage? Past research on China and other settings has partly attributed the capacity for agency to leaders' personalities and to historical contingencies (Chung 2000; Rudolph and Rudolph 2002; Tan 2002; Donaldson 2011). There is little question that some individuals are more politically adept, risk-acceptant, and inclined to innovate than others, or that fortuitous sequences of events can provide leaders favorable opportunities to act. Nevertheless, proactive leadership and policy implementation can also reflect more deeply rooted structural factors. Subnational leaders who enjoy solid elite backing and have privileged access to political information are more likely to challenge the status quo than leaders in precarious positions. Similarly, governments with political and material resources should have an easier time carrying out their policy visions. It is thus crucial to look more systematically at the structural aspects of subnational power.

\section{Structural conceptions of subnational government capacity}

Seeking to define subnational authority in ways that can be applied across multiple national contexts, scholars like Marks et al (2008), Falleti (2010), and Dickovick (2005) take a fine-grained look at how policy powers and resources are divided between subnational units and the central government. Such work identifies different structural aspects of subnational capacity, including administrative, fiscal, and political dimensions. China scholars, too, have pointed to these structural factors to explain variation in the strength of subnational units.

Taking a structural view, subnational government capacity depends in part on the formal powers and resource endowments that enable provincial authorities to exercise power within their territories - what Marks et al (2008) call "self rule." One key dimension is policymaking

\footnotetext{
${ }^{3}$ For instance, Li (1997) notes Shanghai’s unusually high degree of influence in central decision-making.
} 
authority, or the extent to which administrative and legislative powers are devolved to regional governments. Depending on the extent to which a subnational government has institutionalized authority to set rules or make policy decisions in different realms, it is easier or harder to enact policies based on its own priorities (Falleti 2010; Marks et al 2008; Dickovick 2005). For instance, many China scholars have noted how the devolution of administrative powers increases subnational governments' ability to promote local economic development. Li (1997) describes how Guangdong's special policies in the late 1970s and 1980s allowed it to pursue reforms that brought localized economic benefits, while Chung (2010) notes how deputy-provincial cities' heightened powers give them a leg up in economic competition.

Another key dimension of subnational capacity concerns fiscal and financial power. The distribution of fiscal resources, spending responsibilities, and taxation and financial powers across different government levels affects the ability of a subnational government to advance its policy priorities. When a subnational government has abundant resources in its coffers, or has the authority to raise new fiscal revenues or borrow large amounts of money, it can more easily fund key projects and programs (Falleti 2010; Dickovick 2005). In the Chinese context, scholars like Lieberthal and Oksenberg (1988), Luo and Shen (2008), and Solinger and Jiang (forthcoming) point out that subnational governments with more resources of their own have greater autonomy in their spending decisions, while those that depend on higher levels for assistance are more beholden to higher levels' demands.

While structural approaches focus on the powers and resources vested in subnational governments, they recognize that subnational governments' ability to achieve their goals also depends on having influence in national-level politics, or what Marks et al (2008) call "shared rule.” As Tarrow (1978) observes,

...'local autonomy' cannot be measured as the simple residual of the administrative functions that are left over after the center takes its share, nor as the level of financing that the center bestows on the periphery (for this can be as much a sign of peripheral influence as of central governmental power), but by the political resources and mechanisms of territorial representation that allow subnational units to utilize the center to their advantage (20-21).

Structural approaches thus highlight the institutions of territorial representation and political accountability that define subnational authorities' relationship to the central government (Falleti 2010; Hutchcroft 2001; Marks et al 2008). In China, of course, such institutions profoundly 
shape subnational units' autonomy and influence. The fact that provincial leaders are appointed by the party center ensures that, at the end of the day, political accountability flows upward. Similarly consequential is the fact that most delegations to China's National Party Congress and National People's Congress meetings are organized by province, which keeps territorial interests salient in national politics. However, within these basic arrangements, there are important differences in provinces' political relations with the center. As Huang (1996) and Sheng (2009) argue, for instance, central control over provincial leaders is tighter in some cases than others, as "centralist" provincial leaders (those who have previously served in the central party-state or concurrently hold Politburo seats) are more likely to comply with the center's wishes than "localists." Meanwhile, provinces do not enjoy equal representation in key political institutions. Certain provinces have more Central Committee members than others, and a subset of provinces have leaders concurrently sitting on the Politburo.

\section{Strengths and limitations of structural approaches}

Existing structural approaches do much to clarify the foundations of subnational government capacity. By disaggregating subnational power into different dimensions, each important in its own right, such approaches offer a clear and broadly applicable language for talking about subnational government capacity. In doing so, they provide at least a partial answer to the question of why some subnational units are better at orchestrating major policy programs than others: other things equal, subnational units are more capable of acting autonomously and mobilizing state resources when they have broad policymaking authority, strong economic bases and fiscal capacity, and enjoy formal standing in central political institutions. Furthermore, by carefully delineating different types of resource endowments and governance authority, such approaches make possible rigorous measurement and comparison of subnational capacity.

Yet, perhaps because they have sought to maximize rigor, structural conceptions of subnational government capacity often focus on what is analytically cleanest while leaving other important factors out of the picture. Structural approaches stress what we might call the delimited authority and resource endowments of subnational governments: they look mainly at how powers are divided between central authorities and subnational units, and they focus on formal, institutionalized authority and resources rather than on softer structures like political networks or 
cultural systems. While this is understandable, even deliberate, ${ }^{4}$ it means that such approaches struggle to explain how or when structural power translates into effective subnational agency.

One difficulty relates to the fact that, despite acknowledging the multilevel character of subnational government, structural approaches tend to focus heavily on the distribution of power between center and provinces, without doing much to unpack the sub-provincial level. This is problematic insofar as it treats subnational powers and resources in an aggregated fashion, taking the idea of a subnational unit too literally. Of course, in reality, subnational units contain multiple territorial and bureaucratic blocs, pieces that may or may not work together in a coordinated fashion. Totaling up the aggregate resources that nominally belong to a subnational unit thus does not give a clear picture of the resources directly at the disposal of provincial leaders. More information about the internal structure and workings of subnational units is needed before we can say how, or whether, different types of power and resources cumulate.

Another issue relates to structural approaches' focus on the formal distribution of authority and resources. Presumably, the broader the formal powers and resource base of a given subnational unit, the more power and autonomy it should enjoy. However, because formal powers come with formal responsibilities, the practical meaning of formal authority is more ambiguous than it first seems, and depends on where agency and discretion reside. When a subnational government accounts for a larger share of fiscal spending relative to the central government, for instance, this could suggest that it has greater discretion over the allocation of resources, but it could also mean that it has greater spending obligations to meet. Along similar lines, scholars have different interpretations of what it means when provincial leaders concurrently hold Politburo seats. Some, including Sheng (2009), regard this as a check on provincial autonomy, insofar as Politburo members are seen as being co-opted by the Party center. As Lam (2010) asserts, however, "the meaning of provincial representation on these central institutions is far from immediately clear...Provincial representation can either be a measure of provincial clout or one of national integration." To know the practical implications, we need more information about the political context and relationships at work.

The question of interest here is how readily a subnational government can launch policies and mobilize support behind them. While the delimited resources and powers of a province

\footnotetext{
${ }^{4}$ This is often deliberate, of course. Marks et al (2008) acknowledge that they are only trying to capture the "formal authority" of subnational governments, without tackling the more complex question of why some subnational governments are more powerful than others when it comes to influencing policy outcomes and politics.
} 
certainly tell us something about its capacity to undertake major initiatives, we must also look at the matrix of political relationships in which subnational governments operate. Getting things done is not just about formal powers and resource endowments; it is also about how governments relate to their own territories and interface with the central state.

\section{Towards a broader conception of subnational government capacity}

To understand subnational governments' capacity to orchestrate strategies of development and governance, we must take into account the internal and external connective structures that allow subnational governments to take the initiative and exert leverage over other actors. On the one hand, it is the degree of cohesion within subnational units as much as their resource endowments and formal policy powers that shapes their capacity for action. On the other hand, it is informal as well as institutionalized linkages between subnational governments and the central state that determine how much political access and leverage they possess. We can expect subnational governments to be most capable of acting autonomously and mobilizing state resources, I argue, when they have cohesive political elites and internal organizational structures, and when they enjoy privileged political ties to central authorities.

\section{Internal connections: organizational centralization and tight-knit elites}

One key determinant of subnational governments' ability to take initiative and mobilize resources is their degree of inward cohesion - how internally connected and coordinated they are in terms of political elites and administrative organization. When subnational units truly function as units, they are better able establish priorities, take action, and sustain efforts over time. Scholarship on state-led development by Kohli (2004), Montero (2001), Murali (2013) and others has stressed the importance of governmental cohesion for "purposive" and effective policymaking. To make and execute a plan, a provincial or municipal unit must achieve consensus internally and coordinate action across different functional and territorial sub-units. When the set of elite decision-makers is tight-knit, reaching and sustaining consensus on policies should be easier. And when subnational leaders have firm control over their bureaucratic or territorial sub-units, they can compel these units to take supporting actions and lend resources. Even when subnational units have limited resources at their disposal, they may be able to achieve large cumulative effects by concentrating resources on key priorities and sustaining their efforts 
over time. Conversely, when elite decision-makers in a subnational unit have conflicting interests and visions, or the territorial and functional sub-units of a subnational government are not fully under its control, orchestrating action - and sustaining efforts over time - is far more difficult.

At least two types of internal connections are likely to matter in shaping a province's capacity for taking action and mobilizing resources. A subnational unit's cohesion partly is a question of how homogenous and like-minded its political elites are. When top leaders, such as the members of a provincial party standing committee, share political, organizational, or regional identities, they are more likely to work as a team on behalf of their unit's territorial interests. ${ }^{5}$ By contrast, when elite decision-makers in a subnational unit lack shared identities, or when subnational decision-making bodies also include leaders of lower-level territorial units with more parochial interests, consensus and teamwork should be more elusive.

Cohesion also depends on the degree of organizational centralization within subnational units. There is variation across countries and subnational units in the extent to which power and resources are concentrated at any particular tier of government. Intermediate levels of government like provinces can be stronger or weaker relative to the center and localities (Hutchcroft 2001). ${ }^{6}$ In the Chinese context, Mertha (2005) uses the term "soft centralization" to convey a similar idea: authority and resources can be centralized within provincial units even as provinces maintain a certain degree of autonomy from the center. The key question where cohesion is concerned is how much internal devolution or fragmentation of authority exists inside a subnational unit. When resources and administrative authority are devolved to lower levels, coordinated action is likely to be more difficult. On the other hand, when provincial units are internally consolidated in administrative and fiscal terms, with provincial-level control over key resources, this should make coordinated action easier.

\footnotetext{
${ }^{5}$ Beyond formal institutions, cultural and ideational factors can also affect the internal cohesion of subnational units. For instance, as Singh (2010) and Kennedy (2014) note in their analysis of India's regional development politics, the extent to which a given subnational unit has a strong political tradition and sense of collective identity can affect the ease of making and carrying out policies in the name of that unit. In China, some provinces and localities historically have had stronger regional identities and greater regional autonomy than others (Whitney 1970; Lieberthal and Oksenberg 1988, 341). This may continue to affect the degree of autonomy they enjoy vis-à-vis higher levels, as well as the degree of legitimacy and broader public and elite support subnational policy initiatives enjoy.

${ }^{6}$ As Hutchcroft (2001) notes, “.... an important question of decentralization, whether deconcentration or devolution, involves specification of which level is to be strengthened. It is quite possible, for example, that "decentralization" could build up the provinces at the expense of both the national and the municipal levels of government. This process may lack a name, but it does exist as an empirical reality."
} 
External connections: privileged political ties to higher-level authorities

Another determinant of subnational units' ability to act autonomously and mobilize resources behind their initiatives is the extent to which they - and, more specifically, their top leaders and bureaucracies - enjoy privileged ties to higher-level authorities. Clientelistic relations or career-based ties with higher-level political or bureaucratic leaders help subnational authorities obtain useful resources and information, and may embolden them to take action. ${ }^{7}$

China scholars have long stressed how privileged connections to central party and government leaders can empower subnational authorities (Chung 2000; Lieberthal and Oksenberg 1988, 350-351). First, such ties can make it easier for subnational leaders to mobilize state resources behind their initiatives (Tan 2004; Shih 2008; Shirk 1993). Higher-level patrons may press state institutions to lend material or organizational support for the initiatives of their protégés at lower levels. Even in the absence of overt higher-level intervention, the knowledge that a given subnational leader has friends in high places may make state agencies more likely to extend support. Second, ties with high-level leaders can provide subnational actors with crucial information about central politics and policymaking that can help them recognize key opportunities. When central policies are ambiguous, or when new central policies are in the offing, ties to higher-level leaders can help subnational authorities get a clearer picture of new opportunities, and also of what the center will tolerate at the subnational level (Chung 2000). Third, ties with high-level leaders can provide subnational authorities the political cover to launch bold policies (Ibid.; Tan 2004). Insofar as personal political ties make subnational leaders' promotion prospects less dependent on adherence to meritocratic standards imposed from above (Shih et al 2012), well-connected leaders may ironically have greater latitude to pursue regional interests. A subnational leader who enjoys high-level backing should also have an easier time pursuing policies that produce clear losers as well as winners, since backlash is less likely to derail his or her promotion chances.

\footnotetext{
${ }^{7}$ While such ties to higher-level actors might at first glance appear to be a constraint on the autonomy of subnational authorities, arguably such ties on balance enhance the ability of subnational leaders to take action and to mobilize resources behind their goals. Unlike the formal relationships of accountability that subnational authorities in centralized systems have to their political and administrative superiors (such as China's cadre evaluation system), informal, patron-client style relationships of accountability are based less on the governance behavior of subordinates and more on expectations of political loyalty. What matters most to high-level patrons at the center probably is not whether a client at the provincial level executes his policy vision to the letter but whether this client provides political support at key moments.
} 
Close connections between provincial bureaucracies and central state agencies may play a similar, if less visible, role in facilitating flows of knowledge and resources between the center and individual provinces. When provincial bureaucracies have close working relationships with central ministries and state institutions, they gain inside information about central policy goals and opportunities to obtain resources. They are likely to have greater ease navigating complex central government approval processes for their plans and projects. To take an example from the Indian context, Sinha (2005) details how the state of Gujarat's longstanding bureaucratic ties with the central government helped it extract policy benefits and resources from New Delhi, while West Bengal's weaker ties to central ministries made it hard to obtain central support.

\section{Subnational government capacity as connective power}

In sum, we can understand subnational governments' capacity to take the initiative in policymaking and mobilize state resources as depending substantially on connective structureson how internally cohesive provinces are, and on whether they have privileged political ties to higher levels. Building on past work by China scholars, this understanding of subnational capacity puts heavy emphasis on political agency. By focusing on the connective structures that make agency possible, however, we can avoid conflating the outcomes being explained - bold initiatives and effective bargaining by subnational leaders - with causally prior conditions.

According to this conception of capacity, subnational governments can undertake major initiatives even when they lack some of the forms of structural power highlighted by comparative scholars. Of course, provinces that enjoy decision-making authority across various policy realms, robust fiscal resources and powers, and representation in national-level political institutions should have greater autonomy from the central state and an easier time accomplishing things on their own. However, orchestrating major policy programs is not just about autonomy from higher levels; it is also a question of whether provinces operate as cohesive units, and how effectively they can mobilize policy support and financing from localities below and the center above.

To demonstrate the utility of this conception of subnational government capacity, the following section presents two brief case studies from the realm of regional development policy. As these cases show, understanding subnational government capacity in terms of connective power, and taking a genuinely multilevel view of subnational politics, can help explain why what 
seem to be strong provinces sometimes struggle to realize their policy goals, and why what appear to be weak provinces are sometimes capable of great feats.

\section{Subnational government capacity in action: regional planning in Hunan and Jiangsu}

Regional development policy has long been a key aspect of economic governance in the PRC, and has experienced a renaissance since the 1990s (Fan 1995; Wei 2000; Li and Wu 2012). Efforts to shape the spatial distribution of economic activity and people, and to coordinate the development of cities, industry, and infrastructure, have taken shape at various scales and involved party-state actors at multiple levels. Regional planning has become an especially critical policy tool for provincial governments in recent years, given that provincial authorities preside over multiple cities and mediate resource flows and administrative relations between Beijing and localities (Gu et al 2012). With much at stake, regional development is a policy area marked by conflicts between different territorial and sectoral interests. Regional planning has thus been a political challenge (Xu 2008; Lam 2010), and provincial authorities have shown varying abilities to realize their goals.

In what follows, I examine the differing outcomes of attempts by provincial governments to coordinate regional development across major metropolitan areas in the provinces of Hunan and Jiangsu. In Hunan, provincial policymakers persisted in a strategy of building up and integrating their capital city region for well over a decade, and managed to mobilize large-scale central support for the initiative as well. This outcome is somewhat surprising given Hunan's profile as a poor interior province with limited fiscal resources, low rankings for institutional quality, and a modest profile in national politics. As I explain, however, the provincial establishment's cohesion and connections enabled it to build momentum behind its development agenda and then mobilize outside resources. By contrast, in Jiangsu, a strong province by conventional standards, provincial authorities struggled to carry out a similar regional strategy. We can understand Jiangsu's difficulty coordinating regional development in terms of the province's lack of internal cohesion.

\section{Building a "comprehensive reform pilot zone" in Hunan}

In recent decades, Hunan has worked to transform its provincial capital of Changsha and the nearby cities of Zhuzhou and Xiangtan into a larger, more integrated metropolitan area able 
to serve as a "growth pole" (zengzhang ji) for the province more broadly. The provincial leadership formally adopted a strategy of Changsha-Zhuzhou-Xiangtan (CZX) economic integration in 1997, hoping to realize a vision that had existed in varying forms since the $1950{ }^{8}{ }^{8}$ In the following years, Hunan laid out plans to build advanced infrastructure and industry in the Changsha region and economically integrate the three cities (Liangxing ban 2011).

The goal of turning Changsha into one of China's most dynamic cities and integrating the capital city region was an audacious one. As of the mid-1990s, Changsha remained a minor metropolis, with an urban population around 1.5 million and a relatively small and inwardlooking economy. Making up around 15 percent of provincial GDP, the city did not even dominate Hunan's economy (China Data Online (CDO); author's calculations). And, despite the three cities' proximity, Changsha, Zhuzhou, and Xiangtan were territorially balkanized. Infrastructural and industrial linkages between the cities remained weak; the cities had historically grown away from one another, and city officials had used a variety of market barriers and interventions to protect local interests (Tong 2011).

Despite a disadvantageous starting point, Hunan over the following decade made major strides in building up the Changsha region economically and weaving the metropolitan area together. During the late 1990s and early 2000s, large-scale investment and policy support contributed to booming urban growth in the once-sleepy Changsha, and provincial efforts to build modern industry clusters and enhance transportation links between the three cities gained speed (Liangxing ban 2011; Jaros 2014). By the mid-2000s, GDP growth in the CZX region was dramatically outpacing that of the rest of Hunan. ${ }^{9}$

Hunan's most significant breakthrough came in 2007, when provincial leaders won recognition for the $\mathrm{CZX}$ region as a national-level "comprehensive reform pilot zones" (zonghe peitao gaige shiyanqu). In December 2007, the region, along with Wuhan in Hubei, gained central approval to establish a pilot zone for "construction of an energy-conserving and environmentally friendly society." Obtaining this approval was no mean feat; competition among China's provinces to gain such status had been fierce. As Lam (2010) notes, "from 2005 to 2007,

\footnotetext{
${ }^{8}$ In some form, this goal dates back to the 1950s, when provincial authorities in Hunan proposed the idea of building up Changsha, Zhuzhou, and Xiangtan into a Mao Zedong City. The idea resurfaced in the 1980s, with calls by provincial government researchers for a CZX economic area to help spur faster economic growth and reform in the province. See Liangxing ban (2011).

${ }^{9}$ Between 1997 and 2005, Hunan's share of GDP had climbed from 16 percent to 23 percent, and between 20012005, Changsha captured 30 percent of FAI in Hunan (CDO; author's calculations).
} 
16 provincial units formally applied to the State Council for the status, while many more indicated their intention to do so." Hunan became one of the first several provinces to host a comprehensive reform pilot zone, preceded only by Shanghai (2005), Tianjin (2006), Sichuan (2007), and Chongqing (2007).

Quickly taking advantage of this special designation, ${ }^{10}$ Hunan moved to scale up its development plans for the CZX region and build stronger regional governance institutions. Meanwhile, the provincial leadership launched several new infrastructure and industry projects in the CZX region to boost the region's economic output and physically knit Changsha and neighboring cities together (Jaros 2014). ${ }^{11}$ The burst of institutional reforms and large-scale investment in the late 2000s contributed to very rapid economic growth in the CZX area, and helped Changsha emerge as one of inland China's most dynamic cities. By 2010, Hunan's capital had a per capita GDP level higher than that of the eastern metropolis of Nanjing (CDO)

Hunan's realization of its goal rapidly to build up and integrate the CZX region is striking for a province that, by conventional standards, did not rank as a strong subnational unit. Hunan had long faced serious fiscal challenges, relying heavily on higher-level assistance to cover revenue shortfalls (CDO; author's calculations). Hunan was also a province known for low institutional quality, receiving poor marks for its business environment (World Bank 2006). Hunan had not had a particularly high profile in national politics during the reform era, and Hunan's capital city, overshadowed by nearby Guangzhou and Wuhan, had not historically served as a major economic or administrative center. As Lam (2010) notes, the selection of cities like Wuhan and Chongqing as sites for early comprehensive reform pilot zones "was almost a foregone conclusion." This was hardly the case for Changsha.

While Hunan fell short on conventional dimensions of subnational government capacity, however, Hunan rates as a strong province if we apply a different set of standards. Though it may have lacked in subnational autonomy, resources, and political influence in a formal, institutional sense, Hunan had the advantage of connective power. Hunan's leaders had

\footnotetext{
${ }^{10}$ As Heilmann and Melton (2013) note, state-level approval of regional development plans gives provinces political authorization - a so-called 'imperial sword' (shangfang baojian) - to embark on new governance experiments and mobilize policy support and financing from state institutions.

${ }^{11}$ For example, Hunan launched work on an inter-city commuter railway system to link Changsha, Zhuzhou, Xiangtan, and other nearby cities (Liangxing ban 2011a). Efforts to build a major automotive industry cluster in Changsha's Economic and Technological Development Zone also took off (China Small and Medium City Task Force 2013).
} 
privileged political ties at the center, and the provincial establishment was relatively cohesive. A closer look reveals that these factors were crucial as Hunan pursued its CZX regional strategy.

At the moment when Hunan managed to win central-level recognition and backing for its CZX regional strategy, the province enjoyed special backchannels to the center by virtue of its top leaders. In 2006, the year before it obtained special designation for the CZX pilot zone, Hunan gained not one but two rising star leaders with career backgrounds and political ties in Beijing. Zhang Chunxian, appointed as Hunan's provincial party secretary in early 2006, had previously served as Minister of Transportation. This experience gave him useful experience with infrastructure megaprojects and left him with a range of personal contacts at the center. ${ }^{12}$ Meanwhile, Zhou Qiang, appointed as Hunan's governor later in the same year, was another rising star in China's party establishment with rumored links to high-level party leaders. Prior to his appointment in Hunan, Zhou had worked in the Ministry of Justice, and he also had past experience in China's Communist Youth League leadership (Li 2010).

Having such high-profile and well-connected leaders in place enhanced Hunan's ability to bargain with Beijing for aid, and provided political cover for bold policies at the provincial level. Zhang Chunxian and Zhou Qiang played an active role in lobbying Beijing for the CZX pilot zone policy (Liangxing ban 2011, 6-11). As one central government researcher who participated in negotiations between provincial and central leaders over the details of the CZX regional plan remarked, Hunan's leaders showed exceptional “proactiveness" (jijixing) in pressing for support (Author's interview in Beijing 2012). They had repeated meetings and exchanges of letters with central leaders including Premier Wen Jiabao and National Development and Reform Commission chief Ma Kai. At the same time, Zhang and Zhou pursued explicitly biased development policies within Hunan. Even at a moment when growing regional disparities between the Changsha area and other parts of Hunan were generating resentment within Hunan, Zhang publicly called for "using the law of uneven development, firmly upholding priority for the advantageously places, [...] and making the CZX urban cluster into the leading zone for new-style industrialization" (Zhang 2009, 9). Hunan's leaders evidently felt secure enough politically to tout policies that left many localities out in the cold.

\footnotetext{
${ }^{12}$ Indeed, Zhang boasted of the benefit of these personal ties for his ability to attract investment to and get things done in Hunan (21 Shiji jingji baodao 3/17/2006).
} 
If the political profiles and connections of top leaders were important to Hunan's ability to take action and mobilize resources for the CZX strategy, the cohesion of the larger provincial establishment was similarly important to the success of Hunan's regional strategy. Zhang and Zhou made rapid progress with the CZX initiative in part because they were able to build on foundations laid by years of focused efforts. After Hunan adopted the CZX economic integration strategy in 1997, provincial leaders, government departments, and policy intellectuals oversaw a series of CZX-related development plans and projects. The CZX Urban Agglomeration Plan, which would serve as a key template for the 2008 CZX Pilot Zone's regional plan, was drafted over several years in the early 2000s and formally approved in 2005 - the first such plan for an inland province. In the decade after 1997, a variety of specialized plans were drawn up to speed the integration of industry, infrastructure, and urban governance in the CZX region, and the provincial government invested heavily in the capital city region's key development zones including the Changsha Economic and Technological Development Zone and the Changsha High Technology Development Zone - to groom new clusters of advanced industry and expand Changsha's urban footprint. The provincial government even physically relocated its offices and affiliated institutions in 2004 to a new campus on Changsha's south side in order to facilitate southward expansion of the city toward Zhuzhou (Jaros 2014, 221). And, after 2004, when provincial officials learned about the possibility of winning special status for the CZX region as a comprehensive reform pilot zone, Hunan's Development and Reform Commission launched research and planning work (Liangxing ban 2011, 6-11). In a deeper sense, then, it was a decade of focused work by the provincial establishment that set the stage for late 2000s breakthroughs.

In turn, it was Hunan's internal cohesion as a political-administrative unit that made such action possible. Despite its limited resource endowments and political profile, Hunan displayed greater internal centralization of administrative authority and resources than many provinces. Sub-provincial cities in Hunan are comparatively weak in economic and political terms. As a latecomer to reform and opening, Hunan saw less devolution of administrative authority to subprovincial levels than some provinces. Even though Hunan was fiscally weak overall, its fiscal power was relatively centralized. Wong $(2002,25-26)$ notes the comparatively high ratio of provincial-level expenditure to prefectural-level expenditure in Hunan in the late 1990s. Meanwhile, Hunan's provincial establishment was also unusually cohesive in a political sense. Provincial-level decision-making was more insulated from sub-regional pressures than in many 
provinces, because none of the province's secondary cities held a seat on the provincial party standing committee (China Directory, various years). And Hunan's strong regional identity, distinctive dialect, and prominent subnational political tradition endowed the provincial unit with symbolic authority (Platt 2007). These factors arguably made it easier to orient policymaking around an agenda of provincial-level economic competitiveness.

The experience of Hunan thus demonstrates how, even in a province weak by conventional standards, internal cohesion and political ties to higher-level elites can make it possible for a subnational government to launch a bold policy initiative and line up support for it.

\section{Jiangsu's failed Metropolitan Circle strategy}

At the same time the CZX regional strategy was taking off in Hunan, Jiangsu attempted to launch an urban-regional development initiative for its own economic heartland. Provincial officials formally unveiled the Suzhou-Wuxi-Changzhou Metropolitan Circle plan in 2002. Issued by Jiangsu's Construction Department, the plan envisioned an array of transportation and utilities infrastructure projects that would link the three cities together and thereby create a more integrated, economically competitive urban region.

In practice, however, Jiangsu had great difficulty implementing the Metropolitan Circle strategy. By the count of Luo and Shen (2008), 10 out of 17 major projects outlined under the plan ran into severe setbacks. One particularly embarrassing defeat for provincial authorities came on the issue of where to build a new international airport for the region: the provincial government was unable to impose its preferred location of Changzhou (Ibid.; Luo 2011). Meanwhile, instead of collaborating to forge tighter infrastructural and market linkages as provincial leaders had hoped, Suzhou, Wuxi, and Changzhou continued to protect their own turf, seeking closer ties to Shanghai instead. Faced with frustrating results and local pushback, the provincial government largely abandoned efforts to implement the plan in the following years. Thereafter, the attention of provincial leaders turned toward a new regional strategy focused on promoting industry growth along Jiangsu's Yangtze River belt. ${ }^{13}$

\footnotetext{
${ }^{13}$ Jiangsu's Riverside Development strategy achieved more implementation success than the Metropolitan Circle plan, but it too ultimately encountered implementation difficulties and mounting political pushback. Jiangsu changed tack again in the late 2000s, announcing in 2007 that it would prioritize a Coastal Development strategy.
} 
One might have expected regional planning efforts to proceed more smoothly in a setting like Jiangsu. With an above-average per capita income and a large fiscal base, ${ }^{14}$ high institutional quality, ${ }^{15}$ and a high national profile, Jiangsu had long been regarded as an economic powerhouse and leader among China's provinces. Based on several structural indicators of subnational authority, it would have ranked as a strong province.

But, despite the power and resources contained within Jiangsu, and the province's high profile on the national stage, Jiangsu lacked internal cohesion of the sort seen in Hunan. As Jacobs (1999) notes, "although Jiangsu clearly ranks as an important province, paradoxically the province itself appears weak" (139). Notwithstanding Jiangsu's overall fiscal strength, the province exhibited internal fiscal decentralization, with the provincial level accounting for a lower proportion of fiscal expenditures than in settings like Hunan (Wei 2000, 173; Wong 2002, 25-26). Cities like Suzhou and Wuxi had strong economic and fiscal bases in their own right, giving them a high level of autonomy in development matters, and limiting provincial leverage over them. As powerful, self-interested economic players, the cities were hard to rein in, as were their competitive tactics (Author's interviews in Jiangsu 2013).

Meanwhile, Jiangsu's political establishment was less insulated from these local interests than Hunan's. Unlike in Hunan, where the provincial capital was the only city whose leader held a seat on the provincial party standing committee, it was typical in Jiangsu not only for the leader of the provincial capital, Nanjing, but also for leaders from Suzhou and Wuxi to hold seats on the standing committee (China Directory, various years). This meant that multiple territorial interests were represented at the highest levels of provincial politics, making consensus on major policy issues more difficult. Indeed, according to one urban planner involved with the Metropolitan Circle strategy, the fact that the plan was issued in the name of an individual provincial department, rather than backed with the full and unambiguous authority of the provincial leadership, hurt its prospects for implementation (Author's interview in Jiangsu 2012).

Also conspiring against the success of the Metropolitan Circle strategy was Jiangsu's lack of a strong provincial-level identity. The province has conspicuous regional differences and localism historically has outweighed allegiance to the provincial unit (Jacobs 1999, 141).

\footnotetext{
${ }^{14}$ With a per capita income of 11,765 yuan in 2000 , Jiangsu ranked sixth among China's provincial units. The province also ranked as China's fourth largest generator of local fiscal revenue in 2000. See China Data Online. ${ }^{15}$ Several of Jiangsu's cities ranked among the best in China in a 2005 World Bank survey in terms of their institutional environment for foreign and domestic firms. See World Bank (2006).
} 
According to urban planners and policy experts in Jiangsu, many officials from the SuzhouWuxi-Changzhou region had little cultural or career-based affinity for the Nanjing-based provincial establishment, and thus felt little enthusiasm for supporting provincial policies. In addition, the high economic and political status of these cities meant they had their own channels for liaising with the central government. As such, they could at times bypass the provincial government and go directly to the center to seek support (Author's interviews in Jiangsu 2013).

Seen alongside the case of Hunan, then, Jiangsu's experience underscores the importance of subnational governments' connective power. Even provinces that are strong in terms of resource endowments can struggle to carry out major policy programs if they lack internal cohesion. Although Jiangsu was a more important socioeconomic entity than Hunan, Hunan's government was able to leverage its internal and external connections to great political effect.

\section{Conclusion}

This article has argued for conceptualizing subnational government capacity in a way that emphasizes political agency while also clarifying the structural conditions for agency. To successfully carry out strategies of regional development or governance, subnational governments must be able to take the initiative in policymaking and mobilize resources both internally and externally. Departing from structural conceptions of government capacity that focus on the formal, delimited powers and resources provinces have at their disposal, this article has highlighted the structures of connective power that enable subnational governments to take action and exert leverage over other political and economic players. First, I have argued that the ability of subnational units to orchestrate policy programs depends on their level of internal administrative centralization and elite cohesion. Second, I have argued that subnational units' ability to exploit opportunities and resources from the central state depends on provincial authorities' informal links with higher-level political elites. These kinds of connective structures, which include political networks, informal institutions, and even shared regional identities, may shape policy outcomes as much as provinces' formal powers and resource endowments.

A broader conception of subnational government capacity helps to explain why Chinese provinces that seem strong by conventional standards sometimes have difficulty orchestrating major policy initiatives in practice. I have illustrated the importance of connective power through case studies of regional development policy in Hunan and Jiangsu. Though it rated as a weak 
province in terms of its resource endowments and national profile, Hunan managed to bring to fruition a major regional development strategy for its capital region. This political feat depended on the province's internal cohesion, which made possible more than a decade of persistent work to implement the CZX strategy. It also depended on provincial leaders' privileged ties to the central leadership, which in the late 2000s helped Hunan obtain extensive central support for what remained in essence a provincial program. Jiangsu had a higher political and economic profile than Hunan, yet it had greater difficulty carrying out a regional development initiative of its own due to a lack of internal cohesion.

At a more general level, this paper has echoed calls by scholars like Zheng (2007), Gibson (2005), and Hutchcroft (2001) to move beyond a central-local optic and take seriously the multilevel character of subnational politics. By focusing on how provincial governments simultaneously negotiate relationships with actors above and below, and by reframing the challenge of leadership as a question of maintaining internal cohesion while exploiting external linkages, we can start to bridge the agency-structure divide that often hampers political analysis. 


\section{References}

Note: Interviews were conducted with government policy experts, urban planners, and local academics in Nanjing and Suzhou during 2012 and 2013. Interview subjects are kept anonymous in accordance with the author's approved research protocol. Additional information on the nature and timing of interviews can be provided upon request.

21 Shiji jingji baodao (21 世纪经济报道). “一个中部农业大省的机会 (A Central Agricultural Province's Opportunity)," March 17, 2006. www.cnki.com.cn.

Cheung, Peter T.Y., Jae Ho Chung, and Zhimin Lin, eds. Provincial Strategies of Economic Reform in Post-Mao China: Leadership, Politics, and Implementation. Studies on Contemporary China. Armonk, NY: M.E. Sharpe, 1998.

China Data Online. All China Data Center, University of Michigan, Accessed 2012-2015.

www.chinadataonline.org.

China Directory (in Pinyin and Chinese). Tokyo: Radiopress, 1999.

China Small and Medium City Task Force, China City Economy Academic Association Small and Medium Sized City Economic Development Committee (中国中小城市科学发展研究课题组、中国城市经济学会中小城市经 济发展委员会). 长沙县两型发展模式研究 (A Study of Changsha County's Two-Type Development Model). Beijing: Social Science Documents Press, 2013.

Chung, Jae Ho. Central Control and Local Discretion in China: Leadership and Implementation During Post-Mao Decollectivization. Oxford: Oxford University Press, 2000.

- Cities in China : Recipes for Economic Development in the Reform Era. London: Routledge, 1999.

. "Chapter 6: Deputy-provincial cities: embedded yet de facto players." In Chung, Jae Ho, and Tao-chiu

Lam, eds. China's Local Administration : Traditions and Changes in the Sub-National Hierarchy. London; Routledge, 2010, 111-126.

Dickovick, J. Tyler. "The Measure and Mismeasure of Decentralisation: Subnational Autonomy in Senegal and South Africa." The Journal of Modern African Studies 43, no. 2, 2005: 183-210.

Donaldson, John A. Small Works: Poverty and Economic Development in Southwestern China. Ithaca: Cornell University Press, 2011.

EIU (Economist Intelligence Unit). "China Economy - Hunan and Jiangxi Survive through Harvests.” Economist Intelligence Unit Viewswire, November 14, 2002.

Falleti, Tulia Gabriela. Decentralization and Subnational Politics in Latin America. New York: Cambridge University Press, 2010.

Fan, C. Cindy. "Of Belts and Ladders: State Policy and Uneven Regional Development in Post-Mao China." Annals of the Association of American Geographers 85, no. 3, 1995: 421.

Feng, Chongyi, and Hans J. Hendrischke, eds. The Political Economy of China's Provinces ; Comparative and Competitive Advantage. London: Routledge, 1999.

Forster, Keith. "The Political Economy of Post-Mao Zhejiang: Rapid Growth and Hesitant Reform." In Provincial Strategies of Economic Reform in Post-Mao China, 145-211. Armonk, NY: M.E. Sharpe, 1998.

Gibson, Edward. "Boundary Control - Subnational Authoritarianism in Democratic Countries." World Politics 58,1, 2005 . 
Gu Chaolin 顾朝林, Zhao Min 赵民, and Zhang Jingxiang 张京祥. 省域城镇化: 战略规划研究 (Provincial Urbanization: Strategic Planning Research). Nanjing: Southeastern University Press, 2012.

Heilmann, Sebastian. "Maximum Tinkering under Uncertainty Unorthodox Lessons from China." Modern China 35, no. 4, 2009: 450-62.

Heilmann, Sebastian, and Melton, Oliver. "The Reinvention of Development Planning in China, 1993-2012." Modern China 39, no. 58, 2013.

Hooghe, Liesbet, and Gary Marks. "Beyond Federalism: Estimating and Explaining the Territorial Structure of Government." Publius: The Journal of Federalism 43, no. 2, 2013: 179-204.

Hutchcroft, Paul D. "Centralization and Decentralization in Administration and Politics: Assessing Territorial Dimensions of Authority and Power." Governance 14, no. 1, 2001: 23-53.

Jaros, Kyle A. "The Politics of Metropolitan Bias in China." Doctoral dissertation, Department of Government, Harvard University, 2014.

Jacobs, J. Bruce. “Uneven Development: Prosperity and Poverty in Jiangsu." In The Political Economy of China's Provinces Competitive and Comparative Advantage, 1999.

Murali, Kanta. "Economic Liberalization, Electoral Coalitions and Private Investment in India,” 2011. www.princeton.edu/ ppglobal/.../papers/murali.pdf.

Kennedy, Loraine. The Politics of Economic Restructuring in India: Economic Governance and State Spatial Rescaling. New York: Routledge, 2014.

Kohli, Atul. State-Directed Development : Political Power and Industrialization in the Global Periphery. Cambridge, UK ; Cambridge University Press, 2004.

Lam, Tao-chiu. "Central-Provincial Relationsn amid Greater Centralization in China." China Information 2010, no. 24, 2010: 339.

Liangxing ban (湖南省长株潭两型办, Hunan Chang-Zhu-Tan Two-Type Society Construction Office). “两型社会 ”建设在湖南: 湖南《两型社会》建设的规划体系 (Building an Eco-Friendly and Energy-Efficient Society in Hunan). Changsha: Hunan People's Press, 2011a.

Li, Cheng. "China's Midterm Jockeying: Gearing Up for 2012 (Part 2: Cabinet Ministers)." China Leadership Monitor, no. 32, 2010. www.hoover.org/publications/china-leadership-monitor.

_. "China's Northeast: From Largest Rust Belt to Fourth Economic Engine?" China Leadership Monitor no. 9, 2004. www.hoover.org/publications/china-leadership-monitor.

Lieberthal, Kenneth, and Michel Oksenberg. Policy Making in China: Leaders, Structures, and Processes. Princeton, N.J.: Princeton University Press, 1988.

Li, Linda Chelan. "Provincial Discretion and National Power: Investment Policy in Guangdong and Shanghai, 197893." The China Quarterly, no. 152, 1997: 778-804.

$\mathrm{Li}, \mathrm{Yi}$, and Wu, Fulong. "The Transformation of Regional Governance in China: The Rescaling of Statehood." Progress in Planning 78, no. 2, 2012: 55-99.

Luo Xiaolong (罗小龙). 长江三角洲地区的城市合作与管治 (Urban Cooperation and Governance in the Yangtze River Delta Region). Beijing: Commercial Affairs Press, 2011. 
Luo, Xiaolong, and Jianfa Shen. "Why City-Region Planning Does Not Work Well in China: The Case of SuzhouWuxi-Changzhou." Cities 25, no. 4, 2008: 207-17.

_. "A study on inter-city cooperation in the Yangtze River delta area" Habitat International, 33, 2009, 52-62.

Marks, Gary, Hooghe, Liesbet, and Schakel, Arjan H. "Measuring Regional Authority." Regional \& Federal Studies 18, no. 2-3, 2008: 111-21.

Mertha, Andrew C. "China's 'Soft' Centralization: Shifting Tiao/Kuai Authority Relations.” The China Quarterly 184, 2005: 791-810.

Montero, Alfred P. "Delegative Dilemmas and Horizontal Logics: Subnational Industrial Policy in Spain and Brazil." Studies in Comparative International Development 36, no. 3, 2001: 58.

Rithmire, Meg. Land Bargains and Chinese Capitalism: The Politics of Property Rights under Reform. New York: Cambridge University Press, 2015.

Rudolph, Lloyd, and Susanne Hoeber Rudolph. "The Iconization of Chandrababu: Sharing Soveierignty in India's Federal Market Economy.” Economic and Political Weekly XXXVI, no. 18, 2001.

Sheng, Yumin. "Authoritarian Co-Optation, the Territorial Dimension: Provincial Political Representation in PostMao China (Report).” Studies in Comparative International Development, 44, no. 1, 2009: 71.

Shih, Victor C. Factions and Finance in China : Elite Conflict and Inflation. Cambridge ; Cambridge University Press, 2008.

"Factions Matter: Personal Networks and the Distribution of Bank Loans in China." Journal of Contemporary China 13, no. 38, 2004: 3-19.

Shih, Victor, Christopher Adolph, and Mingxing Liu. "Getting Ahead in the Communist Party: Explaining the Advancement of Central Committee Members in China." American Political Science Review 106, no. 01, 2012: $166-87$.

Shirk, Susan L. The Political Logic of Economic Reform in China. California Series on Social Choice and Political Economy; 24. Berkeley: University of California Press, 1993.

Singh, Prerna. "We-Ness and Welfare: A Longitudinal Analysis of Social Development in Kerala, India." World Development, 39, no. 2, 2011.

Sinha, Aseema. The Regional Roots of Developmental Politics in India : A Divided Leviathan. Contemporary Indian Studies. Bloomington, IN: Indiana University Press, 2005.

Solinger, Dorothy, and Jiang, Ting. "When Central Orders and Promotion Criteria Conflict: Implementation Decisions on the Destitute in Poor Versus Prosperous Cities." Modern China, Forthcoming.

Tan, Qingshan. China's Provincial Party Secretaries. EAI Background Brief; No. 195-196. Singapore: East Asian Institute, National University of Singapore, 2004.

Tan, Qingshan. "Growth Disparity in China: Provincial Causes.” Journal Of Contemporary China 11, no. 33, 2002: 735-59.

Tarrow, Sidney. “Introduction.” In Tarrow, Sidney, Katzenstein, Peter J., and Graziano, Luigi, eds. Territorial Politics in Industrial Nations. New York: Praeger Publishers, 1978. 
Thun, Eric. Changing Lanes in China: Foreign Direct Investment, Local Governments, and Auto Sector Development. Cambridge; New York: Cambridge University Press, 2006.

Tong Zhongxian (童中贤). 城市群整合轮：基于中部城市群整合机制的实证分析 (Integration of Urban Agglomeration: The Empirical Study on Urban Agglomeration Integration Mechanism of Central China). Shanghai: Scientific Press, 2011.

Wei, Yehua Dennis. Regional Development in China: States, Globalization, and Inequality. London, New York: Routledge, 2000.

Whitney, Joseph B.R. “China: Area, Administration, and Nation Building.” Research Paper. Department of Geography, University of Chicago, 1970.

Wong, Christine. "China: National Development and Sub-National Finance - A Review of Provincial Expenditures.” Poverty Reduction and Economic Management Unit, East Asia and Pacific Region, World Bank, April 9, 2002. www1.worldbank.org.

World Bank Poverty Reduction and Economic Management, Financial and Private Sector Development Unit, East Asia and Pacific Region. "China: Governance, Investment Climate, and Harmonious Society: Competitiveness Enhancements for 120 Cities in China (Report No. 37759-CN)," October 2006. Accessed at siteresources.worldbank.org/INTCHINA/Resources/.../120cities_en.pdf.

$\mathrm{Xu}$, Jiang. "Governing City-Regions in China: Theoretical Issues and Perspectives for Regional Strategic Planning." The Town Planning Review 79, no. 2/3, 2008: 157-85.

Yu Jianxing and Wang Shizong. "New Agenda for the Study of Chinese Governance." Journal of Chinese Governance. 1, no. 1 2016, 21-40.

Zhang Chunxian (张春贤). “推进新型工业化要着力在深化、加速、带动上下功夫 (To Push Forward New-Style Industrialization, We Must Gather Strive to Deepen, Accelerate, and Spur along High and Low-Level Work).” In He, Ed., 加强基础产业，推进富民强省 (Stengthen Basic Industry, Push Forward a Rich People and Strong Province). Changsha: Hunan People's Press, 2009.

Zheng, Yongnian. De Facto Federalism in China : Reforms and Dynamics of Central-Local Relations. Hackensack, NJ: World Scientific, 2007. 